\title{
Diet, cuisine and consumption practices of the first farmers in the southeastern Baltic
}

\author{
Harry K. Robson ${ }^{1}$ (D) Raminta Skipitytè $\dot{2}^{2,3} \cdot$ Giedrè Piličiauskienè $^{4} \cdot$ Alexandre Lucquin $^{1} \cdot$ Carl Heron $^{5} \cdot$ Oliver E. Craig $^{1} \cdot$ \\ Gytis Piličiauskas ${ }^{3}$
}

Received: 23 November 2018 / Accepted: 30 January 2019 / Published online: 15 February 2019

(C) The Author(s) 2019

\begin{abstract}
With the arrival of the Early Neolithic Globular Amphora and Corded Ware cultures into the southeastern Baltic, ca. 2900/2800$2400 \mathrm{cal}$ BC, a new type of economy was introduced, animal husbandry. However, the degree to which this transformed the subsistence economy is unknown. Here, we conducted organic residue analyses of 64 ceramic vessels to identify their contents. The vessels were sampled from 10 Lithuanian archaeological sites dating across the Subneolithic-Neolithic transition to the Early Bronze Age (ca. 2900/2800-1300 cal BC). Our results demonstrate that regardless of location or vessel type, many ceramics were used to process aquatic resources. Against our expectations, this association continued even after marked economic change concurrent with the migration of pastoralists from central and southeastern Europe, as evidenced by recent ancient DNA analysis of human remains. Moreover, we observed dairy fats in pottery from all cultures of the Early Neolithic (i.e. Rzucewo, Globular Amphora and Corded Ware) but unlike other regions of Europe, it seems that these were incorporated into indigenous culinary practices. Furthermore, some vessels were used to process plant foods, and others may have been used for the production and/or storage of birch bark tar. However, evidence for domesticated plant processing, for example millet, was absent. We show that organic residue analysis of pottery provides a different picture of past consumption patterns compared to the stable isotope analysis of human remains from isolated burials where a clear dietary shift is evident.
\end{abstract}

Keywords Southeastern Baltic $\cdot$ Neolithic $\cdot$ Bronze Age $\cdot$ Organic residue analysis $\cdot$ Aquatic biomarkers $\cdot$ Ceramic vessels

The Subneolithic period (ca. 5000-2900 cal BC) is marked by the presence of pottery, i.e. a Ceramic Mesolithic, whilst the Neolithic is marked by the presence of domesticates, and represented by the Globular Amphora and Corded Ware cultures.

Electronic supplementary material The online version of this article (https://doi.org/10.1007/s12520-019-00804-9) contains supplementary material, which is available to authorized users.

Harry K. Robson

hkrobson@hotmail.co.uk

Gytis Piličiauskas

gytis.piliciauskas@gmail.com

Raminta Skipityte

raminta.skipityte@ftmc.lt

Giedrè Piličiauskienè

giedrepils@gmail.com

Alexandre Lucquin

alexandre.lucquin@york.ac.uk

Carl Heron

cheron@britishmuseum.org
Oliver E. Craig

oliver.craig@york.ac.uk

1 BioArCh, Department of Archaeology, University of York, Heslington, York YO10 5DD, UK

2 Center for Physical Sciences and Technology, Sauletekio Ave. 3, Vilnius 10257, Lithuania

3 Lithuanian Institute of History, Kražių st. 5, Vilnius 01108, Lithuania

4 Faculty of History, Vilnius University, Universiteto st. 7, Vilnius 01513, Lithuania

5 Department of Scientific Research, The British Museum, Great Russell Street, London WC1B 3DG,, UK 
Fig. 1 Carbon $\left(\delta^{13} \mathrm{C}\right)$ and nitrogen $\left(\delta^{15} \mathrm{~N}\right)$ stable isotope data obtained on human (coloured circles) and faunal bone (dashed boxes) collagen from the southeastern Baltic and adjoining regions dating from the Subneolithic to the Early Bronze Age (data from Antanaitis and Ogrinc 2000; Antanaitis-Jacobs et al. 2009; Eriksson and Howcroft 2014; Eriksson et al. 2003, 2008; Fornander 2013; Heron et al. 2015; Laneman and Lang 2013; Piezonka et al. 2013; Piličiauskas et al. 2017a, b, 2018a; Reitsema 2012; Robson et al. 2016; Sjögren et al. 2016; Skipityte unpublished data; Tõrv and Meadows 2015; this study) (Table S1)

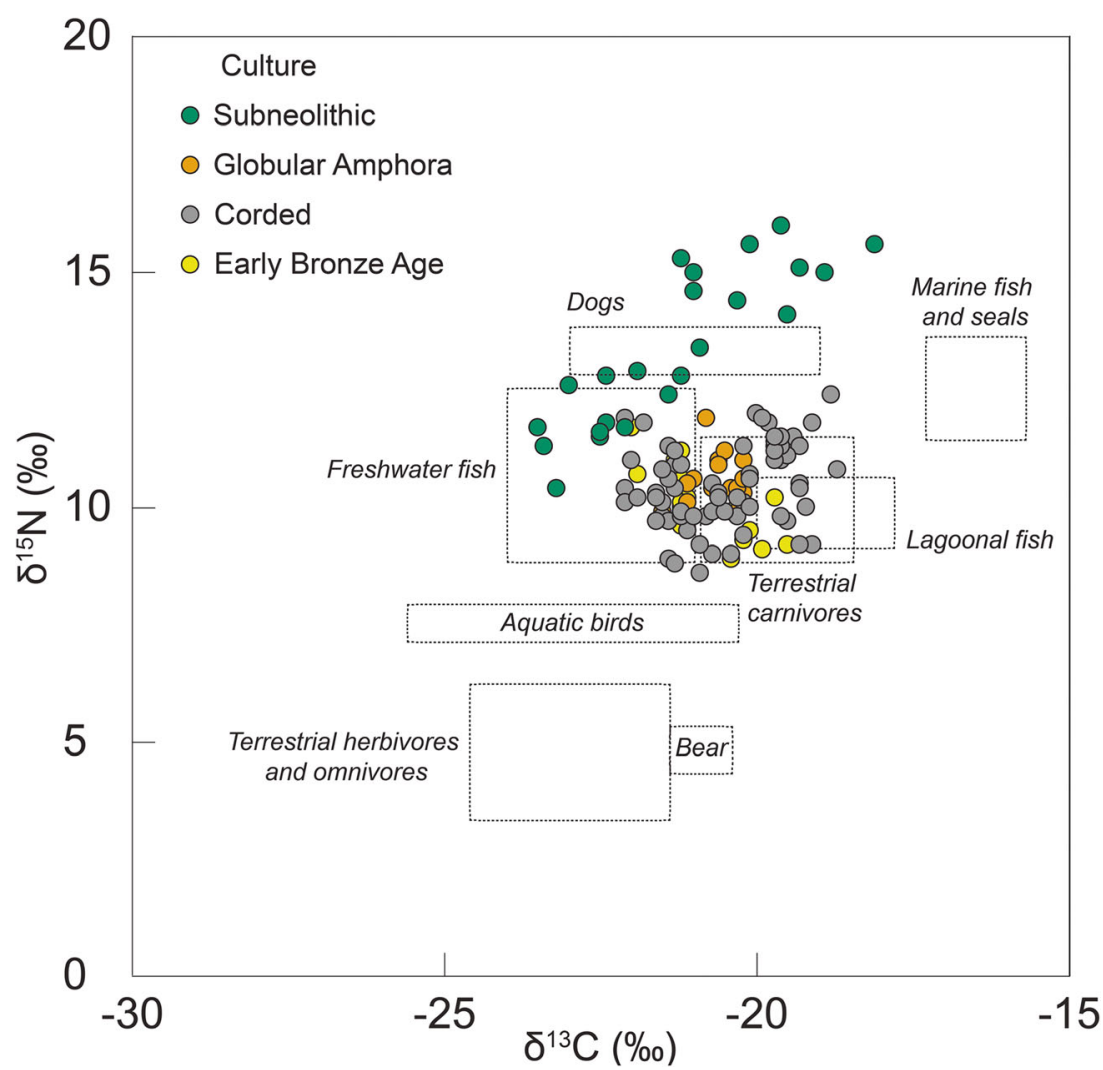

\section{Introduction}

The southeastern Baltic was one of the last regions in Europe to adopt agriculture, ${ }^{1}$ some $2500-1500$ years after it was introduced in adjacent regions to the south. The reasons for this late adoption may seem obvious - the northerly latitudes were far less suitable for growing crops and rearing livestock, whilst indigenous wild game, fish and plants, which characterise the region, could easily have been procured from these densely forested, and highly productive aquatic ecotones (Piličiauskas 2018). It is perhaps harder to understand the eventual imposition of farming in this region, which is first recorded by the appearance of domesticated animals from ca. 2900/28002400 cal BC with the Early Neolithic Globular Amphora (GAC) and Corded Ware (CWC) cultures (Charniauski 1996; Lõugas et al. 2007; Piličiauskas et al. 2017a, b, c; Rimantienè 2002), and then by crop cultivation in the Middle Bronze Age, ca. 1300 cal BC (Piličiauskas et al. 2017c).

One obvious explanation for the arrival of farming in the southeastern Baltic is the northerly mass migration of

\footnotetext{
${ }^{1}$ In this contribution, agriculture refers to the practice of farming, which includes land cultivation for the growing of crops and the rearing of livestock. These terms primarily refer to the GAC and CWC who are culturally linked to the central European Neolithic.
}

pastoralists from regions to the south leading to the replacement of indigenous people and their economy. Indeed, analysis of ancient DNA (aDNA) from skeletal remains in the region demonstrates that both GAC and CWC populations shared some ancestry with central and southeastern Europeans. Whilst the GAC peoples from present day Poland and Ukraine are related to Anatolian farmers (Mathieson et al. 2018; Tassi et al. 2017), the CWC populations had an Eastern European steppe ancestry linking them to the pastoral communities of the Yamnaya Culture (Allentoft et al. 2015; Haak et al. 2015; Jones et al. 2017; Juras et al. 2018; Mittnik et al. 2018; Saag et al. 2017). Yet, the demise of such 'affluent foragers' of this region may not be simply explained by a population replacement by incoming farmers. The aDNA evidence also demonstrates that indigenous 'forager' populations resided and interacted with incoming 'farmers' until at least the mid-3rd millennium BC (Kristiansen et al. 2017; Mittnik et al. 2018), whilst the modern eastern Baltic population still possess the highest proportion of hunter-gatherer ancestry of all Europeans (Lazaridis et al. 2014; Malmström et al. 2009).

Recently, stable isotope analysis of human bone collagen has been used to examine how the diets of incoming groups may have differed from indigenous populations. Data from the region (Fig. 1) shows a broad dietary change from aquaticderived protein diets, with collagen enriched in ${ }^{15} \mathrm{~N}$, in the 
Subneolithic to terrestrial-derived protein diets, depleted in ${ }^{15} \mathrm{~N}$, with the appearance of the GAC and CWC (AntanaitisJacobs et al. 2009; Piličiauskas et al. 2017a, b, c). Nevertheless, it is difficult to quantify the degree of dietary change, and the approach does not completely exclude hunting and fishing during the GAC and CWC. The isotope dataset is also biased by the availability of human remains, which have largely been sampled from single burials or small cemeteries (Piličiauskas 2018) occupying distinct locations in the landscape, which may represent a possible funerary rite perhaps not afforded to all. For instance, despite the fact that there are over $70 \mathrm{CWC}$ sites in Lithuania, there are only 20 known graves (Piličiauskas 2018). Moreover, supporting evidence from the analysis of botanical remains from settlement sites has been much less forthcoming due to the overall poor preservation of macroremains on 'dryland' sites, and a lack of appropriate recovery techniques, especially for older excavations.

Organic residue analysis therefore offers an alternative approach for determining the types of foods commonly consumed and processed in the past, and this method is starting to be widely applied to pottery vessels throughout the Baltic region (e.g. Cramp et al. 2014a; Heron et al. 2015; Oras et al. 2017; Piličiauskas et al. 2018b). One advantage of this technique is based in part on the distinct ceramic typologies that have been confidently assigned to different cultural groups in the region (Fig. 2) (Piličiauskas 2016; Rimantienè 1984). In this region, Comb, Dubičiai, Narva, Neman and Porous wares were produced by Subneolithic hunter gatherers, whereas Rzucewo (RC), GAC and CWC wares are a characteristic of the Early Neolithic (Neolithic I) period. So-called Hybrid wares are defined as having a shell temper, which is a characteristic of Subneolithic pottery, but with ornamentation in the form of cord impressions that are usually associated with the Neolithic. This sequence is followed by more varied pottery types during the Late Neolithic (Neolithic II), and the Early Bronze Age (ca. 2400-1300 cal BC), which are commonly classified as post-Corded Wares. Another advantage is that large pottery assemblages are available from settlement sites throughout the region with many containing multiple typologies or stratified sequences offering the opportunity to examine cultural and temporal changes in utilitarian culinary practices.

\section{Materials and methods}

\section{Sampled sites}

In total, 10 archaeological habitation sites, with large pottery assemblages and thus representative vessels, situated in Lithuania were sampled (S1). In order to assess differences in pottery use, a range of sites situated in different ecotones were selected, i.e. coastal (estuarine/lagoonal), riverine and lacustrine (Fig. 3). The majority of the samples were selected from stratified or short-lived and well-dated sites (e.g. Alksnynė 3 and Daktariškè 5). In total, 28 vessels and 36 carbonised surface deposits, including interior 'foodcrusts' and exterior 'sooted-crusts', were sampled for organic residue analysis; the latter have recently been identified as food residues as opposed to soot from the fire used to heat the vessel contents (Piličiauskas et al. 2018b). A summary of the sampled vessels are provided in Table 1. The bulk carbon $\left(\delta^{13} \mathrm{C}\right)$
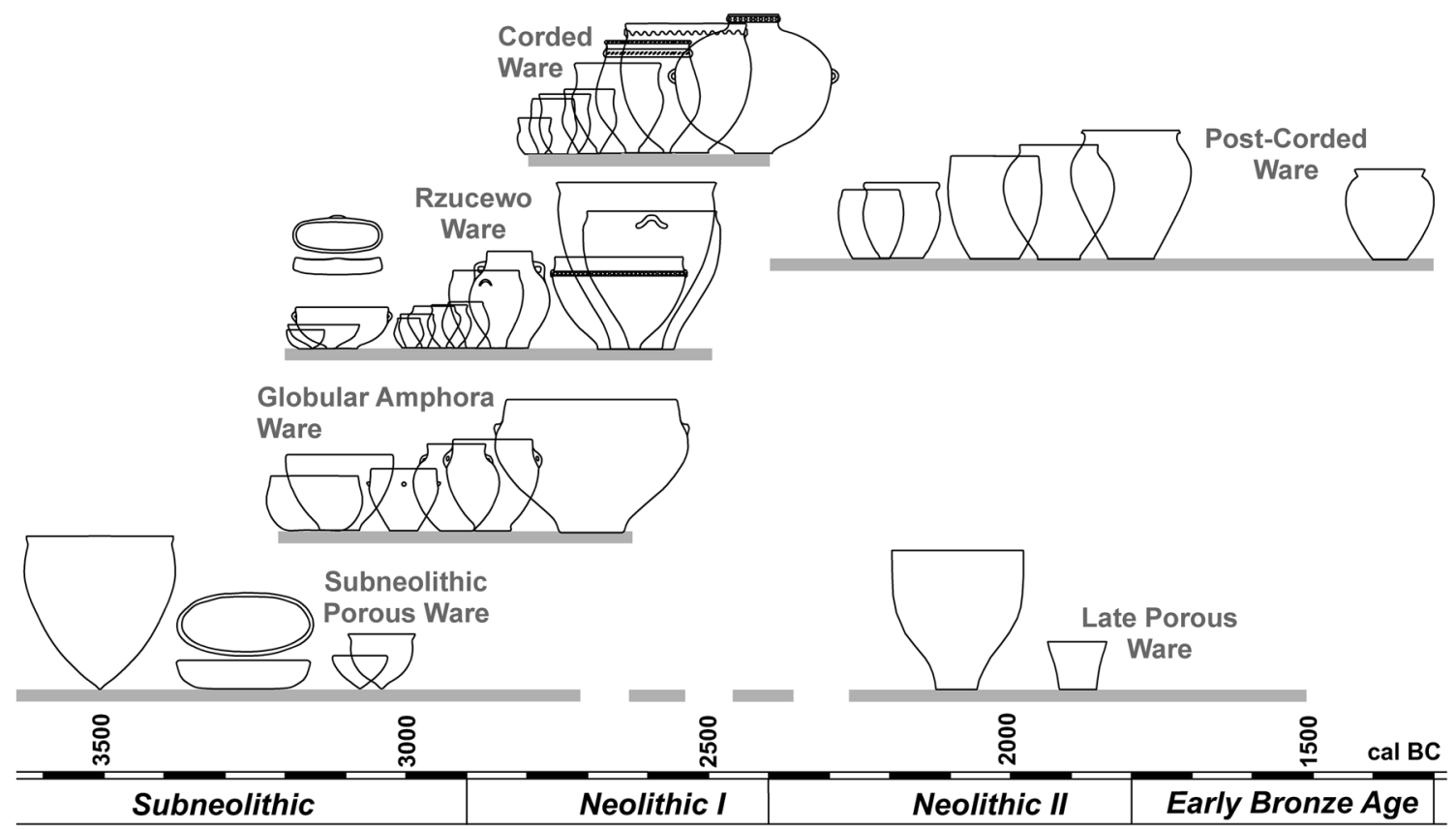

Fig. 2 The pottery sequence in Lithuania. Adapted from Heron et al. (2015) and Piličiauskas (2016) 


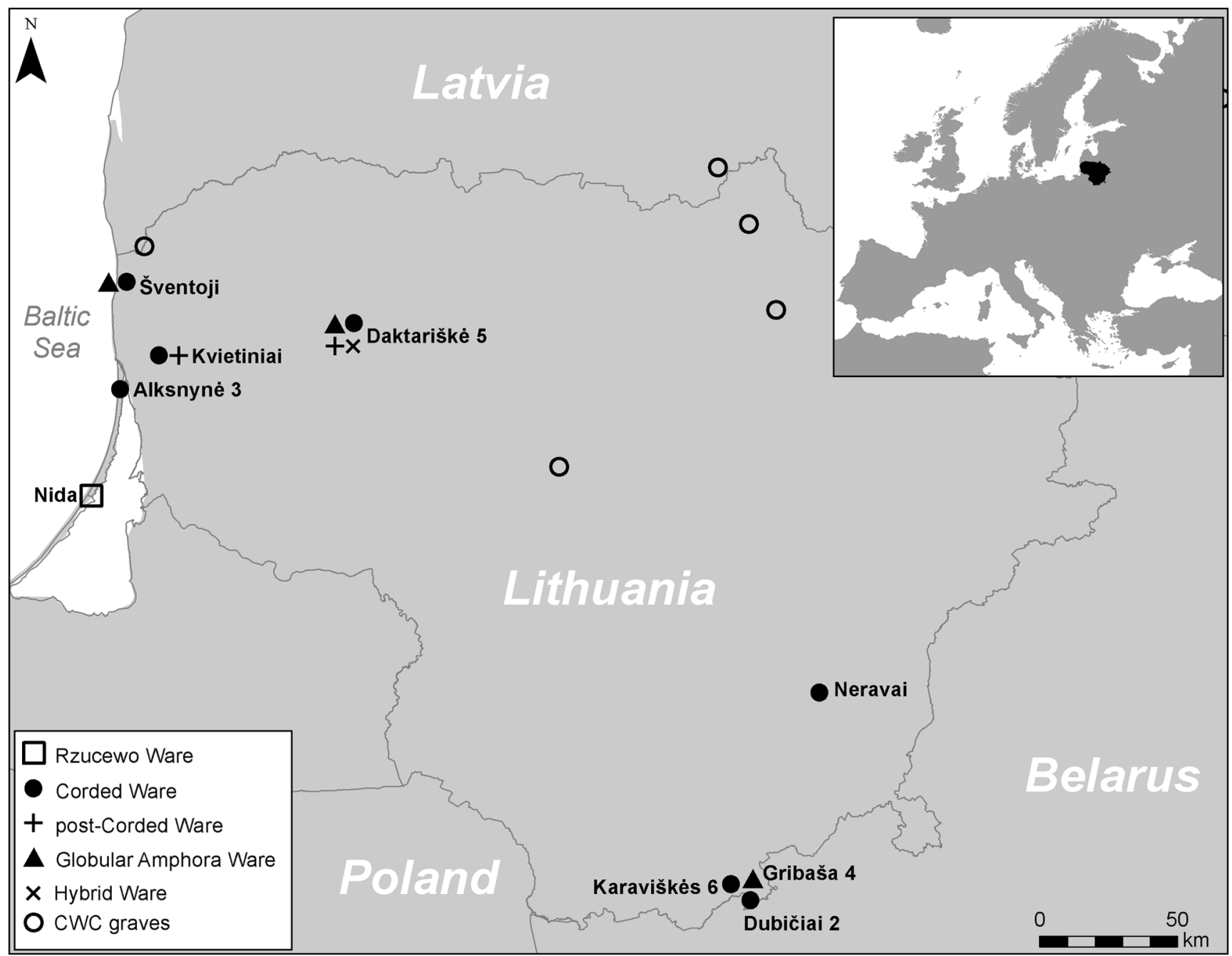

Fig. 3 Map showing the locations of the sites sampled in this study and those sampled previously by Heron et al. (2015). In addition, all CWC burials previously sampled for stable isotope analysis are indicated (see "Discussion"). Insert, map showing the location of Lithuania in relation to Europe

and nitrogen $\left(\delta^{15} \mathrm{~N}\right)$ stable isotope data were complemented with data published elsewhere (Heron et al. 2015; Piličiauskas et al. 2018b).

\section{Bulk isotope ratio mass spectrometry analysis}

Bulk $\delta^{13} \mathrm{C}$ and $\delta^{15} \mathrm{~N}$ stable isotope analysis was undertaken on 36 carbonised surface deposits. Measurements were undertaken at two laboratories: the University of Bradford (UK) and the Centre for Physical Sciences and Technology, Vilnius (Lithuania). The samples were removed directly from the sherds using a scalpel, weighed out into tin capsules and then analysed without any pre-treatment. The samples were analysed in duplicate, and the values averaged where applicable. At Bradford, an ANCA-SL Elemental Analyser linked to a PDZ Europa 20/20 mass spectrometer was used. At Vilnius, an Elemental Analyser Flash EA1112 linked to a Thermo V Advantage Mass Spectrometer was employed. Calibrations and measurement uncertainty are discussed elsewhere (Piličiauskas et al. 2018b).

\section{Sampling for organic residue analysis}

To reduce contamination from the burial environment, the surfaces of the potsherds were removed to a depth of between 1 and $2 \mathrm{~mm}$ using a Dremel drill fitted with a tungsten abrasive bit - this powder was then disposed of. Then, ca. $2 \mathrm{~g}$ of the ceramic powder was removed by drilling to a depth of between 2 and $4 \mathrm{~mm}$ from the interior surfaces of the potsherds. The powder was homogenised using a mortar and pestle. One aliquot was subjected to acidified methanol extraction followed by gas chromatography-mass spectrometry (GC-MS) and gas chromatography-combustion-isotope ratio mass spectrometry (GC-C-IRMS). A second aliquot was solvent extracted and analysed by GC-MS. When present, ca. $20 \mathrm{mg}$ of the carbonised surface residues were removed from 
Table 1 Summary of the samples analysed in this study
Location Pottery typology (wares) Period
Approximate radiocarbon dates (cal BC)
Number of

vessels sampled

\begin{tabular}{|c|c|c|c|c|}
\hline \multicolumn{5}{|l|}{ Alksnynė 3} \\
\hline Lagoon & Corded & Neolithic I & $2500 / 2400$ & 10 \\
\hline \multicolumn{5}{|l|}{ Daktariškè 5} \\
\hline Lakeshore & Globular Amphora & Neolithic I & $2900-2700$ & 5 \\
\hline Lakeshore & Corded & Neolithic I & $2800-2400$ & 10 \\
\hline Lakeshore & Post-Corded & Neolithic II_EBA & $2400-1600$ & 9 \\
\hline Lakeshore & Hybrid & Neolithic I? & $2800-2400 ?$ & 3 \\
\hline \multicolumn{5}{|l|}{ Dubičiai 2} \\
\hline Lakeshore & Corded & Neolithic I & $2800-2400$ & 2 \\
\hline \multicolumn{5}{|l|}{ Gribaša 4} \\
\hline Lakeshore & Globular Amphora & Neolithic I & $2900-2400$ & 2 \\
\hline \multicolumn{5}{|l|}{ Nida } \\
\hline Lagoon & Rzucewo & Neolithic I & $2900-2400$ & 3 \\
\hline \multicolumn{5}{|l|}{ Karaviškès 6} \\
\hline Lakeshore & Corded & Neolithic I & $2800-2400$ & 4 \\
\hline \multicolumn{5}{|l|}{ Kvietiniai } \\
\hline River & Corded & Neolithic I & $2800-2400$ & 6 \\
\hline River & Post-Corded & Neolithic II-EBA & $2000-1200$ & 6 \\
\hline \multicolumn{5}{|l|}{ Neravai } \\
\hline River & Corded & Neolithic I & $2800-2400$ & 1 \\
\hline \multicolumn{5}{|l|}{ Šventoji 1} \\
\hline Lagoon & Corded & Neolithic I & $2700-2400$ & 1 \\
\hline \multicolumn{5}{|l|}{ Šventoji 4} \\
\hline Lagoon & Globular Amphora & Neolithic I & 2700 & 2 \\
\hline \multicolumn{4}{|c|}{ Total number of samples } & 64 \\
\hline
\end{tabular}

the vessel surface using a scalpel. These were homogenised using a mortar and pestle for acidified methanol extraction followed by GC-MS and GC-C-IRMS. A summary of the extraction procedure and analyses performed on each sample is provided in Table $\mathrm{S} 2$.

\section{Acidified methanol extraction}

Lipids were directly extracted and methylated using an acidified methanol extraction procedure (Correa-Ascencio and Evershed 2014; Craig et al. 2013; Papakosta et al. 2015). Briefly, methanol (4 mL) was added to each sample. Then, the samples were ultrasonicated in a water bath for $15 \mathrm{~min}$, acidified with concentrated sulphuric acid $(800 \mu \mathrm{L})$, and vortexed and heated in closed vials for $4 \mathrm{~h}$ at $70{ }^{\circ} \mathrm{C}$. After centrifugation, the acidified supernatants were transferred to sterilised and clean vials. Lipids were extracted with $n$-hexane $(3 \times 2 \mathrm{~mL})$ and filtered through a pipette with potassium carbonate and glass wool to neutralise any sulphuric acid. The extracts were evaporated under a gentle stream of $\mathrm{N}_{2}$ at $37^{\circ} \mathrm{C}$.
The samples were resuspended and transferred to a new vial, and then $10 \mu \mathrm{L}$ of an internal standard $\left(1.0 \mu \mathrm{g} \mu \mathrm{L}^{-1}\right.$ hexatriacontane) was added to each sample before analysis by GC-MS and GC-C-IRMS using published methodologies (S2) (Craig et al. 2007, 2012; Hansel et al. 2004).

\section{Solvent extraction}

Solvent extraction was undertaken using previously published methodologies (Craig et al. 2007; Dudd and Evershed 1998; Hansel and Evershed 2009). Briefly, $10 \mu \mathrm{L}$ of an internal standard ( $n$-tetratricontane) was added to each sample. Then, the samples were ultrasonicated for $15 \mathrm{~min}$ at $25^{\circ} \mathrm{C}$ with three aliquots of dichloromethane:methanol (2:1 vol/vol; $5 \mathrm{~mL})$. The extracts were combined and evaporated under a gentle stream of $\mathrm{N}_{2}$ at $37{ }^{\circ} \mathrm{C}$ to obtain a total lipid extract (TLE). Then, the samples were silylated with BSTFA + TMCS (99:1) at $70{ }^{\circ} \mathrm{C}$ for $1 \mathrm{~h}$ and evaporated to dryness under a gentle stream of $\mathrm{N}_{2}$. Derivatised samples were resuspended in $n$-hexane and directly analysed by GC-MS (S2). 

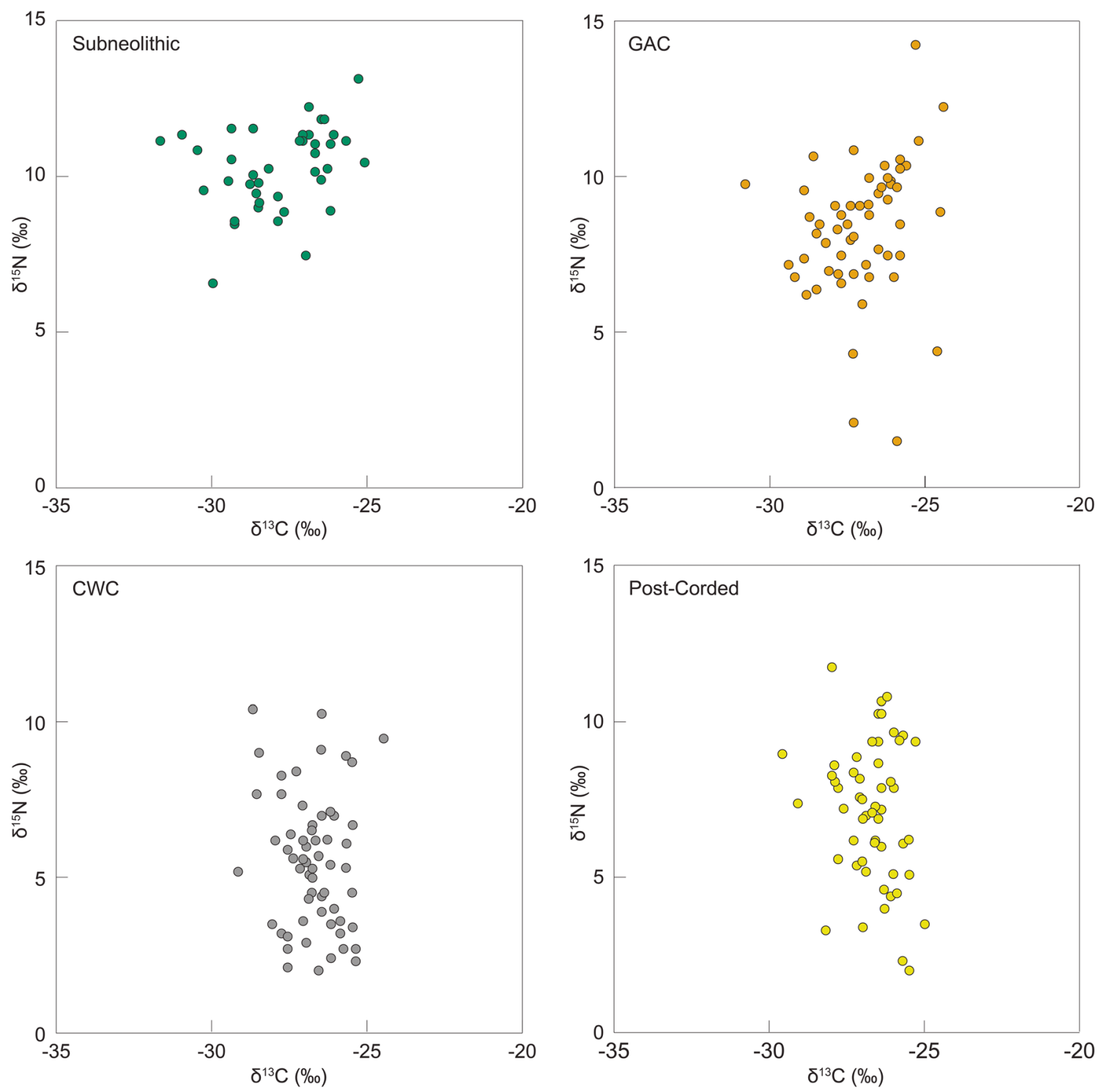

Fig. 4 Bulk $\delta^{13} \mathrm{C}$ and $\delta^{15} \mathrm{~N}$ stable isotope data obtained from carbonised surface residues (data from Heron et al. 2015; Piličiauskas et al. 2018b; this study). The data have been disaggregated according to ware (Table S3)

\section{Instrumentation}

The acidified methanol and solvent extracts were initially analysed by GC-MS (Agilent 7690A Series Gas Chromatograph coupled to an Agilent 5975C Inert XL Mass-Selective Detector with a Quadrupole Mass Analyser and Triple-Axis Detector (Agilent Technologies, Cheadle, Cheshire, UK)) using a DB-5-ms column ((5\%phenyl)-methylpolysiloxane column $(30 \mathrm{~m} \times 0.32 \mathrm{~mm} \times$ $0.25 \mu \mathrm{m}$; J\&W Scientific, Folsom, CA, USA)) in order to calculate the lipid yields and identify the main molecular compounds (S2). However, in order to explore the presence or absence of specific ions related to aquatic organisms, including 4,8,12-trimethyltridecanoic acid (TMTD), pristanic acid, phytanic acid and $\omega$-(o-alkylphenyl) alkanoic acids (APAAs), the majority (49/64) of the acidified methanol extracts were analysed using a DB-23 ((50\%-cyanopropyl)-methylpolysiloxane column (60 m $\times$ $0.25 \mathrm{~mm} \times 0.25 \mu \mathrm{m}$; J\&W Scientific, Folsom, CA, USA)) column in single-ion monitoring mode (SIM) (S2). In total, 18 solvent extracts were analysed by a HT-DB1 GC-MSFID $(100 \%$ dimethylpolysiloxane $(15 \mathrm{~m} \times 0.32 \mathrm{~mm} \times$ $0.1 \mu \mathrm{m})(\mathrm{J} \& W$ Scientific, Folsom, CA, USA) column) to identify monoacylglycerols, triacylglycerols and diacylglycerols associated with plant products (S2), whilst 48 acidified methanol extracts were analysed by GC-CIRMS (Delta $\mathrm{V}$ advantage isotope ratio mass spectrometer (Thermo Fisher Scientific, Bremen, Germany) linked to a Trace 1310 Gas Chromatograph (Thermo Fisher) with a ConFlo IV interface $(\mathrm{CuO}$ combustion reactor held at $\left.850{ }^{\circ} \mathrm{C}\right)$ ) to further distinguish the origins of the different foodstuffs (S2). 
Fig. $5 \mathrm{C}: \mathrm{N}$ atomic ratios and $\delta^{15} \mathrm{~N}$ stable isotope data obtained from carbonised surface residues (data from Heron et al. 2015; Piličiauskas et al. 2018b; this study) (Table S3)

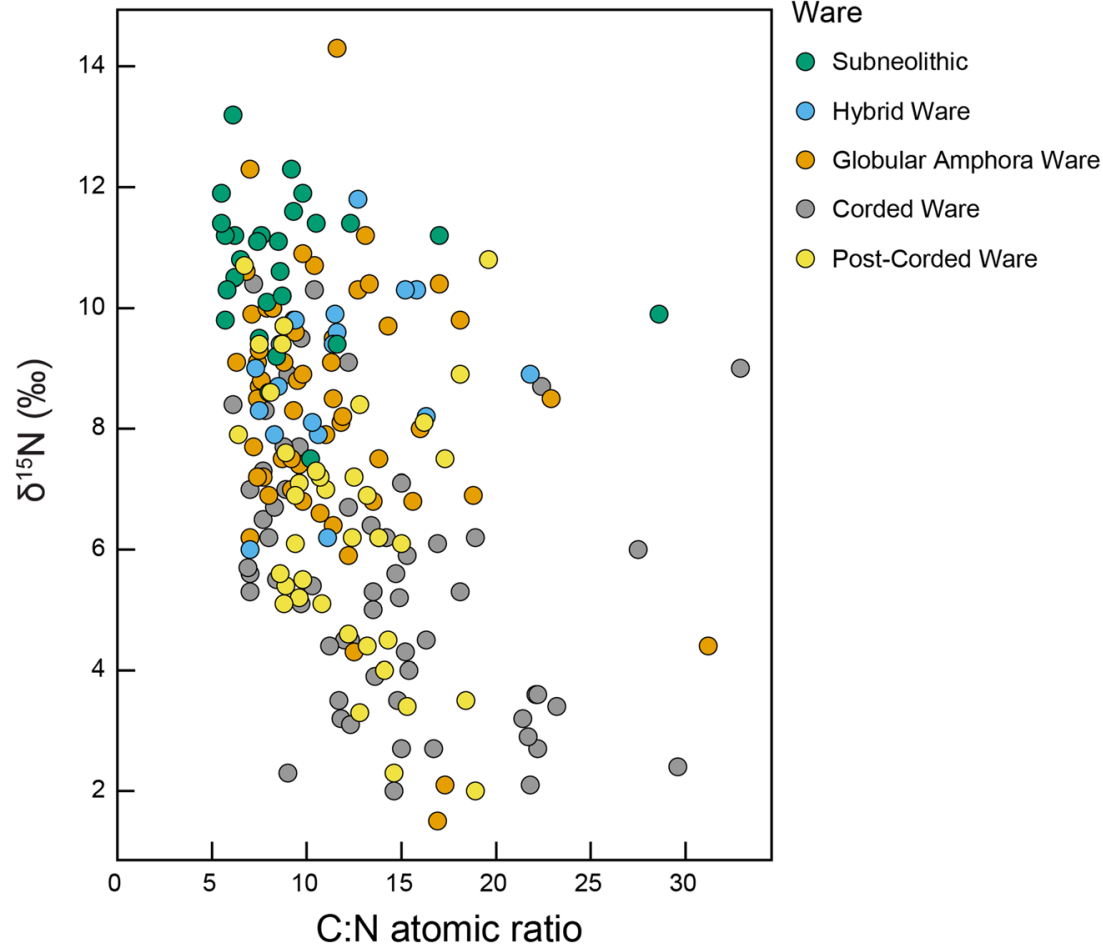

\section{Results}

\section{Bulk carbon and nitrogen stable isotope analysis}

Bulk carbon $\left(\delta^{13} \mathrm{C}\right)$ and nitrogen $\left(\delta^{15} \mathrm{~N}\right)$ stable isotope data were obtained on $36 / 64$ vessels sampled in this study. These data were combined with data $(n=165)$ reported elsewhere (Heron et al. 2015; Piličiauskas et al. 2018b) (Table S3). Despite issues regarding the accuracy of this method (Heron and Craig 2015), $\delta^{13} \mathrm{C}$ values are typically higher in marinederived residues compared to freshwater and terrestrial, whilst $\delta^{15} \mathrm{~N}$ values are generally higher in aquatic-derived residues (>6\%o) compared to terrestrial ( $<6 \%$; Craig et al. 2007). When the data were disaggregated according to period/ware (Fig. 4), there was a significant difference in the distribution of $\delta^{15} \mathrm{~N}$ values between the groups (Kruskal-Wallis $\chi^{2}=93.936$; $p=<0.001)$. On the whole, the foodcrusts from the Subneolithic (i.e. Porous) and GAC vessels had higher $\delta^{15} \mathrm{~N}$ values $(1.5$ to $14.4 \%$; mean $=9.1 \% \circ ; n=102)$ when compared with the CWC and post-Corded Ware vessels (2.0 to $10.8 \%$; mean $=5.9 ; n=99$ ) suggesting differences in their use. This was particularly evident for the CWC vessels derived from inland localities ( 2.0 to $10.4 \%$; mean $=5.0 ; n=46$ ) compared with coastal sites ( 3.6 to $10.3 \%$; mean $=7.2 ; n=14$ ), i.e. terrestrial resources in the hinterland compared with aquatic foodstuffs at the coast (Piličiauskas et al. 2018b). Interestingly, foodcrusts with lower $\delta^{15} \mathrm{~N}$ values also tended to have higher quantities of carbon relative to nitrogen (i.e. high $\mathrm{C}: \mathrm{N}$ atomic ratios; Pearson $\mathrm{R}=-3.8$; $p=<0.001$ )
(Fig. 5). As plant products generally contain less protein, their contribution to the samples with higher $\mathrm{C}: \mathrm{N}$ atomic ratios and lower $\delta^{15} \mathrm{~N}$ values could be implied (Heron et al. 2016; Yoshida et al. 2013).

\section{Organic residue analysis}

In total, 28/31 of the powdered ceramic sherds and 30/33 of the carbonised surface residues yielded sufficient quantities of lipids (Table S4), which were above the minimum amount required for interpretation (Evershed 2008; Craig et al. 2013).

\section{Results of the molecular analysis}

The molecular results obtained by GC-MS are summarised in Table S4. In general, the residues are characterised by degraded animal fats with a high relative abundance of $\mathrm{C}_{16: 0}$ and $\mathrm{C}_{18: 0}$ unsaturated fatty acids and mono-, di- and triacylglycerols. A clear feature of the lipid profiles was that many of the samples (31/64) met the established criteria for the presence of aquatic biomarkers in archaeological pottery (Table S5), which includes APAAs with $\mathrm{C}_{18}$ and $\mathrm{C}_{20}$ carbon atoms, and at least one isoprenoid fatty acid, i.e. TMTD, pristanic or phytanic acid (Evershed et al. 2008a; Hansel et al. 2004). Since APAAs are only formed through extended heating of the pottery (Evershed et al. 2008a; Hansel et al. 2004), their presence confirms that they are derived from the use of the vessel. The ratio of the two naturally occurring phytanic acid diastereomers (\%SSR) was also examined to further 
$\delta^{13} \mathrm{C}_{16: 0}(\%)$

$\delta^{13} \mathrm{C}_{16: 0}(\%)$
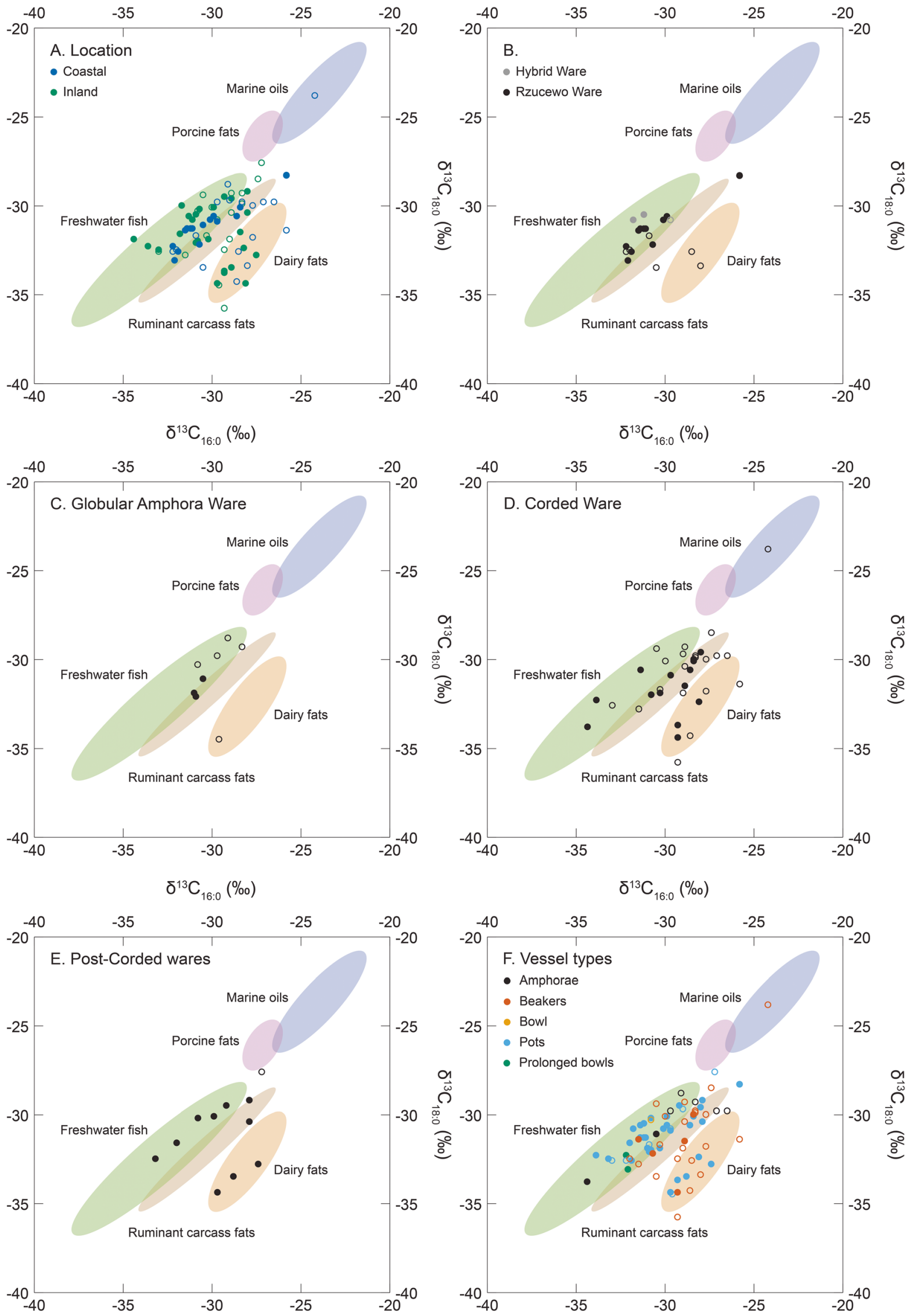
Fig. $6 \delta^{13} \mathrm{C}$ values of $\mathrm{C}_{16: 0}$ and $\mathrm{C}_{18: 0} n$-alkanoic acids extracted from 48/ 64 vessels analysed in this study alongside data $(n=27)$ obtained from contemporaneous vessels from the circum-Baltic region (data from Cramp et al. 2014a; Heron et al. 2015; Piličiauskas et al. 2018a). The ellipses are derived from modern authentic reference animals and are plotted at 68\% confidence (Dudd 1999; Oras unpublished; Oras et al. unpublished; Pääkkönen et al. accepted). Closed circle — sample with aquatic biomarkers, open circle — sample without aquatic biomarkers

discriminate between aquatic and ruminant foodstuffs (Lucquin et al. 2016). Despite this, none of the samples could be securely assigned to either source as they yielded \%SRR values that were within the range for both authentic aquatic oils and ruminant fats.

Molecular evidence for the processing of plant and insect products was infrequent even though a plant contribution to some vessels was supported by the bulk $\delta^{13} \mathrm{C}$ and $\delta^{15} \mathrm{~N}$ stable isotope data (Fig. 5). In total, only a small proportion (13/64) of the sampled vessels yielded long-chain alkanes and traces of odd-chain fatty acids (Table S4), including $\mathrm{C}_{29}$, which may be derived from cuticles and the epicuticular waxes of plants (Raven et al. 1997) or alternatively beeswax (Regert et al. 2001). There was no discernible pattern regarding the presence of these compounds based on location, period/ware or vessel type, or indeed correspondence with the bulk stable isotope data, and some migration of these lipids from the soil cannot be ruled out given their low abundance in the potsherds. Triterpenoids, which are ubiquitously found in terrestrial and marine flora and fauna, were identified in 17/64 of the analysed samples (Table S4). These compounds could be derived from plant products that had been directly processed in the pottery or alternatively from sealing the vessels, wood smoke and even post-depositional contamination. Betulin and/or lupeol were present in a total of 13 vessels (Table S4) indicating the presence of birch bark (Betula sp.) resin (Pollard et al., 2016). Since both were identified in two exterior sooted crusts (DK87 I 4a and Dk 494), they may originate from the fuel used to heat the vessel contents rather than the production of birch bark tar for other purposes. In other cases, these compounds were present alongside animal fats indicating possible reuse of these vessels.

\section{Isotopic analysis of individual fatty acids}

To distinguish vessel use further, 48/64 samples that yielded sufficient fatty acids were analysed by GC-C-IRMS. Carbon stable isotope $\left(\delta^{13} \mathrm{C}\right)$ values were obtained from the two fatty acid methyl esters, methyl palmitate $\left(\mathrm{C}_{16: 0}\right)$ and methyl stearate $\left(\mathrm{C}_{18: 0}\right)$ (Table $\left.\mathrm{S} 6\right)$. In Fig. 6, these data are plotted with data (Table S7) obtained from contemporaneous vessels (Cramp et al. 2014a; Heron et al. 2015; Piličiauskas et al. 2018a) as well as $\delta^{13} \mathrm{C}$ values obtained from modern authentic reference animal fats from the circum-Baltic region (Dudd
1999; Oras unpublished; Oras et al. unpublished; Pääkkönen et al. accepted).

In general, the vessels sampled from the coastal, including estuarine/lagoonal, sites yielded fatty acid $\delta^{13} \mathrm{C}$ values that generally support the presence of aquatic biomarkers, with the majority plotting within the range established for freshwater fish (Fig. 6a). There were some samples, however, that yielded aquatic biomarkers and plotted within the ranges established for ruminant carcass and dairy fats indicating that some mixing of vessel contents had taken place. Interestingly, many vessels sampled from the coastal sites were depleted in ${ }^{13} \mathrm{C}$ when compared with data published from coastal sites elsewhere (Craig et al. 2007, 2011; Heron et al. 2013; Oras et al. 2017). This either indicates that freshwater fish from the Curonian Lagoon and Šventoji palaeolagoon or alternatively resources depleted in ${ }^{13} \mathrm{C}$ from the Baltic Sea (Robson et al. 2016) had been processed in the vessels from the sites of Alksnyne 3, Nida and Šventoji 1 and 4. Organisms depleted in ${ }^{13} \mathrm{C}$ could include seal (Phocidae), or fish that can tolerate a range of salinities, for example three-spined stickleback (Gasterosteus aculeatus).

When the data were disaggregated according to period/ ware, some diachronic patterns emerge. Despite the range of fatty acid $\delta^{13} \mathrm{C}$ values $\left(\delta^{13} \mathrm{C}_{16: 0}=-32.2\right.$ to $-25.8 \%$, $\delta^{13} \mathrm{C}_{18: 0}=-33.5$ to $-28.3 \%$ o) obtained from the RC vessels (Fig. 6b), only two had been solely used to process/store dairy fats; the remainder were used for processing freshwater fish and ruminant carcass fats and mixtures thereof, which was corroborated by the presence of aquatic biomarkers. Similarly, with one exception, the GAC wares were primarily used for processing freshwater fish and/or ruminant carcass fats (Fig. 6c). In contrast, the Corded (Fig. 6d) and postCorded (Fig. 6e) wares had more varied use with vessels yielding fatty acid $\delta^{13} \mathrm{C}$ values indicative of freshwater fish, ruminant carcass and dairy fats. Overall, there was a significant difference (Kruskal-Wallis $\chi^{2}=11.07 ; \mathrm{df}=4 ; p=0.03$ ) in $\Delta{ }^{13} \mathrm{C}\left(\delta^{13} \mathrm{C}_{18: 0}-\delta^{13} \mathrm{C}_{16: 0}\right)$ between wares consistent with a greater frequency of terrestrial (ruminant carcass and dairy) derived fats in the Corded and post-Corded Ware vessels when compared with the other Early Neolithic ceramics (i.e. RC and GAC). There was only one CWC vessel that plotted within the range for marine oils (Fig. 6d), a beaker from the Finnish site of Kirkkonummi Koivistosveden (Cramp et al. 2014a), and one post-Corded Ware pot that may have been used to process porcine fats (Fig. 6e), a pot from the Lithuanian site of Kvietiniai. The one bowl and two prolonged bowls, the latter which have been interpreted as lamps (Heron et al. 2015; Oras et al. 2017), indicated the processing of freshwater fish. Lastly, although many of the pots yielded aquatic biomarkers they plotted within the freshwater fish, ruminant carcass and dairy fat ranges demonstrating that some mixing of vessel contents had taken place. 


\section{Discussion}

\section{Continuity in pottery use with the appearance of domesticates}

Our analyses provide new insights into changing culinary practices with the arrival of domesticated animals with the Early Neolithic CWC and GAC. Previous studies have shown that aquatic resources were extensively processed in huntergatherer ceramics throughout the region (Heron et al. 2015; Oras et al. 2017; Piličiauskas et al. 2018b). The isotope and molecular evidence combined show that the Early Neolithic ceramics from all cultures (i.e. RC, GAC and $\mathrm{CWC}$ ) were used for the processing of aquatic resources, regardless of location or vessel type, compelling evidence for continuity in pottery use beyond the Neolithic transition. Except for the RC wares (Fig. 6b), the youngest samples, dating to the Late Neolithic (Neolithic II) and Early Bronze Age, i.e. postCorded Wares, had the highest frequency of aquatic biomarkers (Fig. 6e) compared to the other Early Neolithic ceramics. In the majority of cases, the isotope data suggest these were organisms from either freshwater or brackish environments that characterise the region. Here, there is no evidence that pottery use radically changed with the introduction of domesticated animals.

Intriguingly, the human stable isotope record shows dietary shift in the Neolithic period away from aquatic resources. One explanation for this discrepancy is that pottery served a wider community than those represented by the burials. Burials may represent a small proportion of society, marking a funerary rite that may not have been afforded by all, and their discovery and excavation is often limited to specific localities. For example, all CWC individuals from Lithuania that have been analysed using stable isotopes (i.e. Benaičiai, Biržai, Plinkaigalis, Gyvakarai; Piličiauskas et al. 2017a, 2018a) are from graves situated in river valleys whereas pottery producing habitation sites are usually located on coastlines and lakeshores (Fig. 3). Finally, it should be noted that the stable isotope analysis of Neolithic individuals does not rule out some consumption of aquatic-derived foods and may be interpreted as dietary broadening to encompass terrestrial products, which is evident through pottery use, especially the CWC ceramics. Equally, food processed in pottery vessels do not necessarily accurately reflect diet.

\section{The appearance of dairying with the Corded Ware culture}

Dairy fats are frequently identified in prehistoric pottery throughout Europe, and this practice is likely to have formed an important part of the economy as soon as domesticated animals were introduced (Copley et al. 2003; Craig et al. 2005; Debono Spiteri et al. 2016; Dunne et al. 2012;
Evershed et al. 2008b). Whilst the southeastern Baltic seems no exception, the frequency of ruminant carcass and dairy fats is much lower than reported in other studies of the Early Neolithic ceramic use due to the fact that aquatic resources continued to be processed. Interestingly, it has been shown through aDNA analysis that selection for the gene conferring the ability of adults to digest the sugars in fresh milk (i.e. lactose persistence) arose during the formation of the CWC (Allentoft et al. 2015) corresponding to the introduction of domesticated animals to this region. Previously, it has been suggested that dairy products are associated with Corded Ware beaker-type 'drinking' vessels over other vessel forms (Cramp et al. 2014a; Heron et al. 2015; Piličiauskas et al. 2018a), which would support this example of gene-culture evolution.

However, when the Lithuanian data are considered, there is no preference for the processing of dairy fats in Corded Ware vessels compared to other Early Neolithic cultures ( $\chi^{2}$ test of independence (group vs presence/absence of dairy) $=2.9981$; $\mathrm{df}=4 ; p$ value $=0.559)$ nor is there any association with dairy fats and vessel type (Fig. 7). Whether dairy products were the preserve of migrants with ancestry in the Yamnaya culture is therefore debatable. Fresh milk can be easily transformed into low-lactose dairy products, such as cheese and yoghurt, and therefore available to all, which may explain their presence more broadly in European Early Neolithic pottery. The analysis of Lithuanian Neolithic and Early Bronze Age ceramic vessels also suggests that dairy fats were mixed with other products, including aquatic foodstuffs (Fig. 6e). Rather than afforded special treatment, it seems likely that dairy products were incorporated into a broader cuisine that in part is derived from previous hunter-gatherer practices.

\section{Comparison with the zooarchaeological evidence}

Although it is often fruitful to compare the data obtained from organic residue analysis with the zooarchaeological evidence (e.g. Oras et al. 2017; Pääkkönen et al. 2016), faunal remains are not well preserved at the majority of Lithuanian Neolithic and Early Bronze Age sites due to the acidity of the soils. When animal bones are present, they are often burnt and highly fragmented $(<1 \mathrm{~cm})$, as in the case of Dubičiai 2, Gribaša 4, Karaviškès 6, Kvietiniai and Neravai, or difficult to assign to a single cultural phase, as in the case of Daktariške 5, Šarnelè, Šventoji 1, 2, 4 and 6. In cases where zooarchaeological remains are better preserved and were found at relatively shortterm sites (e.g. Alksnyne 3, Kretuonas 1C and Nida), they indicate a mixed economy, which incorporated fishing, hunting and animal husbandry (Daugnora and Girininkas 2004; Piličiauskas 2018; Piličiauskas et al. 2017c, 2018a). For instance, at the RC site of Nida, the zooarchaeological evidence demonstrates a mixed economy with a focus on fishing. Here, a range of domesticated and wild mammalian taxa was recovered, which were found alongside freshwater, anadromous 
Fig. 7 Difference in the $\delta^{13} \mathrm{C}$ isotope values $\left(\Delta^{13} \mathrm{C}\right)$ between individual $\mathrm{C}_{18: 0}$ and $\mathrm{C}_{16: 0} n$ alkanoic acids extracted from 48/ 64 vessels analysed in this study alongside data $(n=27)$ obtained from contemporaneous vessels from the circum-Baltic region (data from Cramp et al. 2014a; Heron et al. 2015; Piličiauskas et al. 2018a). The reference ranges, including the median, are derived from modern authentic reference animals (Dudd 1999; Oras unpublished; Oras et al. unpublished; Pääkkönen et al. accepted). Closed circle - sample with aquatic biomarkers, open circle - sample without aquatic biomarkers

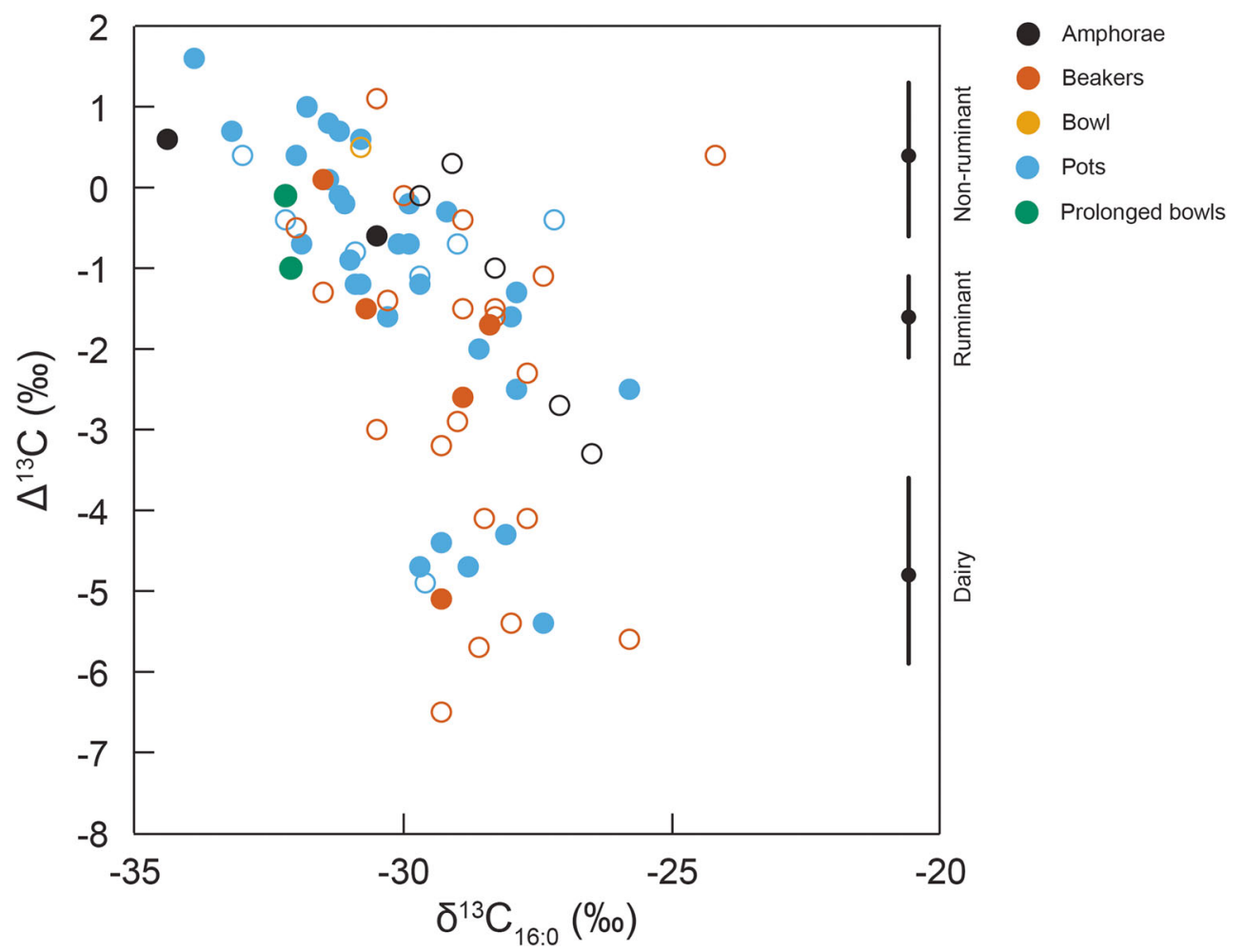

and marine fish (Piličiauskas 2018; Piličiauskienė unpublished data; Schmölcke unpublished data). Similarly, at the CWC site of Alksnyne 3 located nearby, the faunal assemblage demonstrated animal husbandry, freshwater fishing from the Curonian Lagoon and seal hunting (Piličiauskas 2018). Moreover, at the post-Corded Porous Ware site of Kretuonas 1C (ca. 1900-1600 cal BC), located in the hinterland, an assemblage composed of domesticated and wild mammalian taxa was recovered alongside numerous fish remains dominated by northern pike (Esox lucius) $(\mathrm{NISP}=529)$ (Daugnora and Girininkas 2004). Whilst the aforementioned examples demonstrate a mixed economy for the Late Porous Ware (or Late Narva), RC and CWC cultures, it is not possible to characterise the subsistence economy of the GAC with certainty given the generally poor stratigraphic control at many sites (e.g. Daktariškè 5, Šventoji 2, 4 and 6). Regardless, our data corroborate the zooarchaeological evidence demonstrating the processing of domestic and wild animals and their resources in Early Neolithic pottery.

\section{Conclusions}

The new data presented here adds to a growing corpus of data concerning pottery use throughout Europe during the Early Neolithic where some broad trends can be outlined. Where farming and new forms of pottery are introduced to regions occupied by ceramic hunter gatherers, a hybridisation of pottery use emerges that incorporates both wild aquatic foods and domesticated resources, for instance across the Ertebølle and Funnel Beaker transition in the western Baltic (Craig et al. 2007, 2011). In contrast, the majority of pottery used by Neolithic farmers in regions previously occupied by aceramic hunter gatherers was solely used for domestic terrestrial resources, including those from coastal sites, for example the UK (Cramp et al. 2014b) and Mediterranean (Debono Spiteri et al. 2016). One reason for this is that ceramic hunter gatherers generally occupied rich aquatic ecotones, which may be associated with a long-standing tradition of pottery use, for instance the Narva culture (Kriiska et al. 2017; Oras et al. 2017).

Organic residue analysis of over 60 ceramic vessels from throughout Lithuania demonstrates that many of the samples (31/64) were primarily used to process aquatic resources regardless of location (coastal or inland) or vessel type (amphorae, beakers, pots). Interestingly, many of the youngest samples in the dataset, i.e. post-Corded Wares, yielded aquatic biomarkers. Based on these data, we propose that the association between pottery use and aquatic resources may have been intrinsically linked culturally as has been demonstrated elsewhere (Gibbs et al. 2017; Lucquin et al. 2018; Tache and Craig 2015). Moreover, despite demographic change as demonstrated by aDNA analysis (Allentoft et al. 2015; Haak et al. 2015; Jones et al. 2017; Juras et al. 2018; Mittnik et al. 2018; Saag et al. 2017), the introduction of domesticated plants and animals appears not to have transformed economies equally throughout Europe. Initially, it seems likely that incoming CWC pastoralists resided side-by-side with indigenous hunter 
gatherers before elements of the Neolithic package, for instance dairy products, were integrated into their lifeway's. However, analyses of further CWC vessels are required to determine whether this practice was pervasive throughout the occupied region.

Acknowledgements We should like to thank E. Oras and M. Pääkkönen for permission to use unpublished data for the production of the ellipses and reference ranges in Figs. 6 and 7 respectively. H.K.R. would like to acknowledge N. Hausmann for assistance with Fig. 6.

Author contributions H.K.R., O.E.C. and G. Piličiauskas designed the research; H.K.R., R.S., A.L., C.H., O.E.C. and G.Piličiauskas performed the research; G.Piličiauskienè contributed contextual information to aid interpretation; H.K.R., R.S., A.L., C.H., O.E.C. and G.Piličiauskas analysed data; H.K.R., O.E.C. and G.Piličiauskas wrote the paper; all authors were involved in reviewing the manuscript.

Funding information This research was financially supported by the British Academy, the Research Council of Lithuania (APP-6/2016) and the European Research Council (695539), all of which we express our gratitude.

\section{Compliance with ethical standards}

Conflict of interest The authors declare that they have no conflict of interest.

Open Access This article is distributed under the terms of the Creative Commons Attribution 4.0 International License (http:// creativecommons.org/licenses/by/4.0/), which permits unrestricted use, distribution, and reproduction in any medium, provided you give appropriate credit to the original author(s) and the source, provide a link to the Creative Commons license, and indicate if changes were made.

\section{References}

Allentoft ME, Sikora M, Sjögren KG, Rasmussen S, Rasmussen M, Stenderup J, Damgaard PB, Schroeder H, Ahlström T, Vinner L, Malaspinas AS, Margaryan A, Higham T, Chivall D, Lynnerup N, Harvig L, Baron J, Casa PD, Dąbrowski P, Duffy PR, Ebel AV, Epimakhov A, Frei K, Furmanek M, Gralak T, Gromov A, Gronkiewicz S, Grupe G, Hajdu T, Jarysz R, Khartanovich V, Khokhlov A, Kiss V, Koláŕ J, Kriiska A, Lasak I, Longhi C, McGlynn G, Merkevicius A, Merkyte I, Metspalu M, Mkrtchyan R, Moiseyev V, Paja L, Pálfi G, Pokutta D, Pospieszny Ł, Price TD, Saag L, Sablin M, Shishlina N, Smrčka V, Soenov VI, Szeverényi V, Tóth G, Trifanova SV, Varul L, Vicze M, Yepiskoposyan L, Zhitenev V, Orlando L, Sicheritz-Pontén T, Brunak S, Nielsen R, Kristiansen K, Willerslev E (2015) Population genomics of Bronze Age Eurasia. Nature 522:167-172. https://doi.org/10.1038/ nature 14507

Antanaitis I, Ogrinc N (2000) Chemical analysis of bone: stable isotope evidence of the diet of Neolithic and Bronze Age people in Lithuania. Istorija 45:3-12

Antanaitis-Jacobs I, Richards M, Daugnora L, Jankauskas R, Ogrinc N (2009) Diet in early Lithuanian prehistory and the new stable isotope evidence. Archaeologia Baltica 12:12-30

Charniauski M (1996) Materials of Globular Amphora culture in Belarus. BPS 4:87-97
Copley MS, Berstan R, Dudd SN, Docherty G, Mukherjee AJ, Straker V, Payne S, Evershed RP (2003) Direct chemical evidence for widespread dairying in prehistoric Britain. Proc Natl Acad Sci U S A 100(4):1524-1529. https://doi.org/10.1073/pnas.0335955100

Correa-Ascencio M, Evershed RP (2014) High throughput screening of organic residues in archaeological potsherds using direct acidified methanol extraction. Anal Methods 6(5):1330-1340. https://doi.org/ 10.1039/C3AY41678J

Craig O, Chapman J, Heron C, Willis L, Bartosiewicz L, Taylor G, Whittle A, Collins M (2005) Did the first farmers of central and eastern Europe produce dairy foods? Antiquity 79(306):882-894. https://doi.org/10.1017/S0003598X00115017

Craig OE, Forster M, Andersen SH, Koch E, Crombé P, Milner NJ, Stern B, Bailey GN, Heron CP (2007) Molecular and isotopic demonstration of the processing of aquatic products in northern European prehistoric pottery. Archaeometry 49(1):135-152. https://doi.org/ 10.1111/j.1475-4754.2007.00292.x

Craig OE, Steele VJ, Fischer A, Hartz S, Andersen SH, Donohoe P, Glykou A, Saul H, Jones DM, Koch E, Heron CP (2011) Ancient lipids reveal continuity in culinary practices across the transition to agriculture in Northern Europe. Proc Natl Acad Sci U S A 108(44): 17910-17915. https://doi.org/10.1073/pnas.1107202108

Craig OE, Allen RB, Thompson A, Stevens VJ, Heron C (2012) Distinguishing wild ruminant lipids by gas chromatography/combustion/isotope ratio mass spectrometry. Rapid Commun Mass Spectrom 26(19):2359-2364. https://doi.org/10.1002/rcm.6349

Craig OE, Saul H, Lucquin A, Nishida Y, Taché K, Clarke L, Thompson A, Altoft DT, Uchiyama J, Ajimoto M, Gibbs K, Isaksson S, Heron CP, Jordan P (2013) Earliest evidence for the use of pottery. Nature 496(7445):351-354. https://doi.org/10.1038/nature12109

Cramp LJE, Evershed RP, Lavento M, Halinen P, Mannermaa K, Oinonen M, Kettunen J, Perola M, Onkamo P, Heyd V (2014a) Neolithic dairy farming at the extreme of agriculture in northern Europe. Proc R Soc Lond 281:20140819. https://oi.org/10.1098/ rspb.2014.0819

Cramp LJE, Jones J, Sheridan A, Smyth J, Whelton H, Mulville J, Sharples N, Evershed RP (2014b) Immediate replacement of fishing with dairying by the earliest farmers of the Northeast Atlantic archipelagos. Proc R Soc Lond 281:20132372. https://doi.org/10.1098/ rspb.2013.2372

Daugnora L, Girininkas L (2004) Algirdas. Rytu Pabaltijo bendruomenių gyvensena XI-II tūkst. pr. Kr. Lietuvos veterinarijos akademijos leidykla, Kaunas

Debono Spiteri C, Gillis RE, Roffet-Salque M, Navarro LC, Guilaine J, Manen C, Muntoni IM, Segui MS, Urem-Kotsou D, Whelton HL, Craig OE, Vigne J-D, Evershed RP (2016) Regional asynchronicity in dairy production and processing in early farming communities of the northern Mediterranean. Proc Natl Acad Sci U S A 113(48): 13594-13599. https://doi.org/10.1073/pnas.1607810113

Dudd SN (1999) Molecular and isotopic characterisation of animal fats in archaeological pottery. Dissertation, University of Bristol

Dudd SN, Evershed RP (1998) Direct demonstration of milk as an element of archaeological economies. Science 282(5393):1478-1481. https://doi.org/10.1126/science.282.5393.1478

Dunne J, Evershed RP, Salque M, Cramp L, Bruni S, Ryan K, Biagetti S, di Lernia $S$ (2012) First dairying in green Saharan Africa in the fifth millennium BC. Nature 486(7403):390-394. https://doi.org/10. 1038/nature 11186

Eriksson G, Howcroft R (2014) Stable carbon and nitrogen isotope analysis of skeletal remains of humans and pigs. In: Przybyła M, Szczepanek A, Włodarczak P (eds) Koszyce, stanowisko 3. Przemoc i rytuał u schyłku neolitu. Wydawnictwo i Pracownia Archeologiczna PROFIL-ARCHEO Magdalena Dziegielewska, Kraków, pp 109-117 
Eriksson G, Lõugas L, Zagorska I (2003) Stone age hunter-fishergatherers at Zvejnieki, northern Latvia: stable isotope and archaeozoological data. Before Farming 1:1-25

Eriksson G, Linderholm A, Fornander E, Kanstrup M, Schoultz P, Olofsson H, Lidén K (2008) Same island, different diet: cultural evolution of food practice on Öland, Sweden, from the Mesolithic to the Roman period. J Anthropol Archaeol 27(4):520-543. https:// doi.org/10.1016/j.jaa.2008.08.004

Evershed RP (2008) Organic residue analysis in archaeology: the archaeological biomarker revolution. Archaeometry 50(6):895-924. https://doi.org/10.1111/j.1475-4754.2008.00446.x

Evershed RP, Copley MS, Dickson L, Hansel FA (2008a) Experimental evidence for the processing of marine animal products and other commodities containing polyunsaturated fatty acids in pottery vessels. Archaeometry 50(1):101-113. https://doi.org/10.1111/j.14754754.2007.00368.x

Evershed RP, Payne S, Sherratt AG, Copley MS, Coolidge J, Urem-Kotsu D, Kotsakis K, Özdoğan M, Özdoğan AE, Nieuwenhuyse O, Akkermans PM (2008b) Earliest date for milk use in the near east and southeastern Europe linked to cattle herding. Nature 455(7212): 528-531. https://doi.org/10.1038/nature07180

Fornander E (2013) Dietary diversity and moderate mobility - isotope evidence from Scanian Battle Axe Culture burials. J Nordic Archaeol Sci 18:13-29

Gibbs K, Isaksson S, Craig OE, Lucquin A, Grishchenko VA, Farrell TFG, Thompson A, Kato H, Vasilevski AV, Jordan PD (2017) Exploring the emergence of an 'aquatic' Neolithic in the Russian Far East: organic residue analysis of early hunter-gatherer pottery from Sakhalin Island. Antiquity 91(360):1484-1500. https://doi.org/ 10.15184/aqy.2017.183

Haak W, Lazaridis I, Patterson N, Rohland N, Mallick S, Llamas B, Brandt G, Nordenfelt S, Harney E, Stewardson K, Fu Q, Mittnik A, Bánffy E, Economou C, Francken M, Friederich S, Pena RG, Hallgren F, Khartanovich V, Khokhlov A, Kunst M, Kuznetsov P, Meller H, Mochalov O, Moiseyev V, Nicklisch N, Pichler SL, Risch R, Rojo Guerra MA, Roth C, Szécsényi-Nagy A, Wahl J, Meyer M, Krause J, Brown D, Anthony D, Cooper A, Alt KW, Reich D (2015) Massive migration from the steppe was a source for Indo-European languages in Europe. Nature 518:284-285. https://doi.org/10.1038/ nature 14317

Hansel FA, Evershed RP (2009) Formation of dihydroxy acids from Zmonounsaturated alkenoic acids and their use as biomarkers for the processing of marine commodities in archaeological pottery vessels. Tetrahedron Lett 50(40):5562-5564. https://doi.org/10.1016/j.tetlet. 2009.06.114

Hansel FA, Copley MS, Madureira LAS, Evershed RP (2004) Thermally produced $\omega$-(o-alkylphenyl) alkanoic acids provide evidence for the processing of marine products in archaeological pottery vessels. Tetrahedron Lett 45(14):2999-3002. https://doi.org/10.1016/j. tetlet.2009.06.114

Heron C, Andersen S, Fischer A et al (2013) Illuminating the Late Mesolithic: residue analysis of 'blubber' lamps from Northern Europe. Antiquity 87:178-188

Heron C, Craig OE (2015) Aquatic resources in foodcrusts: identification and implication. Radiocarbon 57(4):707-719. https://doi.org/10. 2458/azu_rc.57.18454

Heron C, Craig OE, Lucquin AJA, Steele VJ, Thompson A, Piličiauskas $\mathrm{G}$ (2015) Cooking fish and drinking milk? Patterns in pottery use in the southeastern Baltic, 3300-2400 cal BC. J Archaeol Sci 63:3343. https://doi.org/10.1016/j.jas.2015.08.002

Heron C, Junko H, Katayama Owens M, Yumiko I, Eley Y, Lucquin A, Radini A, Saul H, Debono Spiteri C, Craig OE (2016) Molecular and isotopic investigations of pottery and 'charred remains' from Sannai Maruyama and Sannai Maruyama No. 9, Aomori Prefecture, Japan. Jpn J Archaeol 4(1):29-52
Jones ER, Zarina G, Moiseyev V, Lightfoot E, Nigst PR, Manica A, Pinhasi R, Bradley DG (2017) The Neolithic transition in the Baltic was not driven by admixture with early European farmers. Curr Biol 27(4):576-582. https://doi.org/10.1016/j.cub.2016.12.060

Juras A, Chyleński M, Ehler E, Malmström H, Żurkiewicz D, Włodarczak P, Wilk S, Peška J, Fojtík P, Králík M, Libera J, Bagińska J, Tunia K, Klochko VI, Dabert M, Jakobsson M, Kośko A (2018) Mitochondrial genomes reveal an east to west cline of steppe ancestry in Corded Ware populations. Sci Rep 8(1):11603. https://doi.org/10.1038/s41598-018-29914-5

Kriiska A, Oras E, Lõugas L, Meadows J, Lucquin A, Craig OE (2017) Late Mesolithic Narva stage on the territory of Estonia: pottery, settlement types and chronology. Estonian J Archaeol 21(1):5286. https://doi.org/10.3176/arch.2017.1

Kristiansen K, Allentoft ME, Frei KM, Iversen R, Johannsen NN, Kroonen G, Pospieszny Ł, Price TD, Rasmussen S, Sjögren K-G, Sikora M, Willerslev E (2017) Re-theorising mobility and the formation of culture and language among the Corded Ware Culture in Europe. Antiquity 91(356):334-347. https://doi.org/10.15184/aqy. 2017.17

Laneman M, Lang V (2013) New radiocarbon dates for two stone-cist graves at Muuski, northern Estonia. Estonian J Archaeol 17(2):89122. https://doi.org/10.3176/arch.2013.2.01

Lazaridis I, Patterson N, Mittnik A et al (2014) Ancient human genomes suggest three ancestral populations for present-day Europeans. Nature 513:409-413. https://doi.org/10.1038/nature13673

Lõugas L, Kriiska A, Maldre R (2007) New dates for the Late Neolithic Corded Ware Culture burials and early husbandry in the East Baltic region. Archaeofauna 16:21-31

Lucquin A, Colonese AC, Farrell TFG, Craig OE (2016) Utilising phytanic acid diastereomers for the characterisation of archaeological lipid residues in pottery samples. Tetrahedron Lett 57(6):703707. https://doi.org/10.1016/j.tetlet.2016.01.011

Lucquin A, Robson HK, Eley Y, Shoda S, Veltcheva D, Gibbs K, Heron CP, Isaksson S, Nishida Y, Taniguichi Y, Nakajima S, Kobayashi K, Jordan P, Kaner S, Craig OE (2018) The impact of environmental change on the use of early pottery by East Asian hunter-gatherers. Proc Natl Acad Sci U S A 201803782. DOI: https://doi.org/10.1073/ pnas.1803782115, 7931, 7936

Malmström H, Gilbert MTP, Thomas MG, Brandström M, Storå J, Molnar P, Andersen PK, Bendixen C, Holmlund G, Götherström A, Willerslev E (2009) Ancient DNA reveals lack of continuity between Neolithic hunter-gatherers and contemporary Scandinavians. Curr Biol 19(20):1758-1762. https://doi.org/10. 1016/j.cub.2009.09.017

Mathieson I, Alpaslan-Roodenberg S, Posth C, Szécsényi-Nagy A, Rohland N, Mallick S, Olalde I, Broomandkhoshbacht N, Candilio F, Cheronet O, Fernandes D, Ferry M, Gamarra B, Fortes GG, Haak W, Harney E, Jones E, Keating D, Krause-Kyora B, Kucukkalipci I, Michel M, Mittnik A, Nägele K, Novak M, Oppenheimer J, Patterson N, Pfrengle S, Sirak K, Stewardson K, Vai S, Alexandrov S, Alt KW, Andreescu R, Antonović D, Ash A, Atanassova N, Bacvarov K, Gusztáv MB, Bocherens H, Bolus M, Boroneanț A, Boyadzhiev Y, Budnik A, Burmaz J, Chohadzhiev S, Conard NJ, Cottiaux R, Čuka M, Cupillard C, Drucker DG, Elenski N, Francken M, Galabova B, Ganetsovski G, Gély B, Hajdu T, Handzhyiska V, Harvati K, Higham T, Iliev S, Janković I, Karavanić I, Kennett DJ, Komšo D, Kozak A, Labuda D, Lari M, Lazar C, Leppek M, Leshtakov K, Vetro DL, Los D, Lozanov I, Malina M, Martini F, McSweeney K, Meller H, Menđušić M, Mirea P, Moiseyev V, Petrova V, Price TD, Simalcsik A, Sineo L, Šlaus M, Slavchev V, Stanev P, Starović A, Szeniczey T, Talamo S, TeschlerNicola M, Thevenet C, Valchev I, Valentin F, Vasilyev S, Veljanovska F, Venelinova S, Veselovskaya E, Viola B, Virag C, Zaninović J, Zäuner S, Stockhammer PW, Catalano G, Krauß R, Caramelli D, Zariņa G, Gaydarska B, Lillie M, Nikitin AG, 
Potekhina I, Papathanasiou A, Borić D, Bonsall C, Krause J, Pinhasi R, Reich D (2018) The genomic history of southeastern Europe. Nature 555:197-203. https://doi.org/10.1038/nature25778

Mittnik A, Wang C-C, Pfrengle S, Daubaras M, Zariņa G, Hallgren F, Allmäe R, Khartanovich V, Moiseyev V, Tõrv M, Furtwängler A, Andrades Valtueña A, Feldman M, Economou C, Oinonen M, Vasks A, Balanovska E, Reich D, Jankauskas R, Haak W, Schiffels S, Krause J (2018) The genetic prehistory of the Baltic Sea region. Nat Commun 9(442):442. https://doi.org/10.1038/s41467-01802825-9

Oras E, Lucquin A, Lembi L, Tõrv M, Kriiska A, Craig OE (2017) The adoption of pottery by north-east European hunter-gatherers: evidence from lipid residue analysis. J Archaeol Sci 78:112-119. https://doi.org/10.1016/j.jas.2016.11.010

Pääkkönen M, Bläuer A, Evershed RP, Asplund H (2016) Reconstructing food procurement and processing in Early Comb Ware period through organic residues in Early Comb and Jäkärlä Ware pottery. Fennoscandia Archaeol XXXIII:57-75

Pääkkönen M, Evershed RP, Asplund H (accepted) Compound-specific stable carbon isotope values of modern terrestrial and aquatic animals from the Baltic Sea and Finland as an aid to interpretations of the origins of fatty acids preserved in archaeological pottery. $\mathrm{J}$ Nordic Archaeol Sci

Papakosta V, Smittenberg RH, Gibbs K, Jordan P, Isaksson S (2015) Extraction and derivatization of absorbed lipid residues from very small and very old samples of ceramic potsherds for molecular analysis by gas chromatography-mass spectrometry (GC-MS) and single compound stable carbon isotope analysis by gas chromatography-combustion-isotope ratio mass spectrometry (GCC-IRMS). Microchem J 123:196-200. https://doi.org/10.1016/j. microc.2015.06.013

Piezonka H, Kostyleva E, Zhilin MG, Dobrovolskaya M, Terberger T (2013) Flesh or fish? First results of archaeometric research of prehistoric burials from Sakhtysh IIa, upper Volga region, Russia. Documenta Praehistorica XL:57-73. https://doi.org/10.4312/dp.40. 6

Piličiauskas G (2016) Lietuvos pajūris subneolite ir neolite. Žemės ūkio pradžia. Lietuvos Archeologija 42:25-103

Piličiauskas G (2018) Virvelinès keramikos kultūra Lietuvoje 2800-2400 cal BC. Lietuvos istorijos institutas, Vilnius

Piličiauskas G, Piličiauskienė G, Jankauskas R, Dupras T (2017a) Reconstructing Subneolithic and Neolithic diets of the inhabitants of the SE Baltic coast (3100-2500 cal BC) using stable isotope analysis. Archaeol Anthrop Sci 9(7):1421-1437. https://doi.org/10. 1007/s12520-017-0463-Z

Piličiauskas G, Jankauskas R, Piličiauskienė G, Craig OE, Charlton S, Dupras T (2017b) The transition from foraging to farming (7000 $500 \mathrm{cal} \mathrm{BC}$ ) in the SE Baltic: a re-evaluation of chronological and palaeodietary evidence from human remains. J Archaeol Sci Rep 14: 530-542. https://doi.org/10.1016/j.jasrep.2017.06.004

Piličiauskas G, Kisielienè D, Piličiauskienė G (2017c) Deconstructing the concept of Subneolithic farming in the southeastern Baltic. Veg Hist Archaeobot 26(2):183-193. https://doi.org/10.1007/s00334-0160584-9

Piličiauskas G, Asheichyk V, Osipowicz G, Skipitytė R, Varul L, Kozakaite J, Kryvaltsevich M, Vaitovich A, Lakiza V, Šapolaite J, Ežerinskis Ž, Pamazanau M, Lucquin A, Craig OE, Robson HK (2018a) The Corded Ware culture in the eastern Baltic: new evidence on chronology, diet, beaker, bone and flint tool function. J
Archaeol Sci Rep 21:538-552. https://doi.org/10.1016/j.jasrep. 2018.08.023

Piličiauskas G, Skipitytė R, Heron C (2018b) Mityba Lietuvoje 45001500 cal BC maisto liekanų keramikoje izotopinių tyrimu duomenimis. Lietuvos archeologija 44:9-41

Pollard AM, Heron C, Armitage RA (2016) Archaeological chemistry, 3rd edn. Royal Society of Chemistry, Cambridge

Raven AM, van Bergen PF, Stott AW, Dudd SN, Evershed RP (1997) Formation of long-chain ketones in archaeological pottery vessels by pyrolysis of acyl lipids. J Anal Appl Pyrolysis 40-41:267-285. https://doi.org/10.1016/S0165-2370(97)00036-3

Regert M, Colinart S, Degrand L, Decavallas O (2001) Chemical alteration and use of beeswax through time: accelerated ageing tests and analysis of archaeological samples from various environmental contexts. Archaeometry 43:549-569. https://doi.org/10.1111/14754754.00036

Reitsema LJ (2012) Stable carbon and nitrogen isotope analysis of human diet change in prehistoric and historic Poland. Dissertation, Ohio State University

Rimantienė R (1984) Akmens amžius Lietuvoje. Mokslas, Vilnius

Rimantienė R (2002) Rutulinių amforų kultūra Vakarų Lietuvoje. Lietuvos archeologija 23:41-50

Robson HK, Andersen SH, Clarke L, Craig OE, Gron KJ, Jones AKG, Karsten P, Milner N, Price TD, Ritchie K, Zabilska-Kunek M, Heron $\mathrm{C}$ (2016) Carbon and nitrogen stable isotope values in freshwater, brackish and marine fish bone collagen from Mesolithic and Neolithic sites in central and northern Europe. Environ Archaeol 21(2):105-118. https://doi.org/10.1179/1749631415Y.0000000014

Saag L, Varul L, Scheib CL, Stenderup J, Allentoft ME, Saag L, Pagani L, Reidla M, Tambets K, Metspalu E, Kriiska A, Willerslev E, Kivisild T, Metspalu M (2017) Extensive farming in Estonia started through a sex-biased migration from the Steppe. Curr Biol 27(14):21852193. https://doi.org/10.1016/j.cub.2017.06.022

Sjögren K-G, Price TD, Kristiansen K (2016) Diet and mobility in the Corded Ware of Central Europe. PLoS One 11(5):e0155083. https:// doi.org/10.1371/journal.pone.0155083

Tache K, Craig OE (2015) Cooperative harvesting of aquatic resources triggered the beginning of pottery production in north-eastern North America. Antiquity 89(343):177-190. https://doi.org/10.15184/aqy. 2014.36

Tassi F, Vai S, Ghirotto S, Lari M, Modi A, Pilli E, Brunelli A, Susca RR, Budnik A, Labuda D, Alberti F, Lalueza-Fox C, Reich D, Caramelli D, Barbujani G (2017) Genome diversity in the Neolithic Globular Amphorae culture and the spread of Indo-European languages. Proc R Soc Lond 284(1867):20171540. https://doi.org/10.1098/rspb. 2017.1540

Tõrv M, Meadows J (2015) Radiocarbon dates and stable isotope data from the Early Bronze Age burials in Riigiküla I and Kivisaare settlement sites, Estonia. Radiocarbon 57(4):645-656. https://doi. org/10.2458/azu_rc.57.18459

Yoshida K, Kunikita D, Miyazaki Y, Nishida Y, Miyao T, Matsuzaki H (2013) Dating and stable isotope analysis of charred residues on the incipient Jomon pottery (Japan). Radiocarbon 55(2-3):1322-1333. https://doi.org/10.2458/azu_js_rc.55.16377

Publisher's note Springer Nature remains neutral with regard to jurisdictional claims in published maps and institutional affiliations. 